FACTA UNIVERSITATIS

Series: Teaching, Learning and Teacher Education Vol. 4, Nº 2, 2020, pp. 87 - 100

https://doi.org/10.22190/FUTLTE2002087N

Original research paper

\title{
EAP STUDENTS' PERCEPTIONS ABOUT CONCORDANCE-BASED LEARNING OF ACADEMIC VOCABULARY AND FORMULAIC EXPRESSIONS
}

\author{
UDC 811.111'367.625.1:81'37; 811.111:378.18; 811.111'374
}

\begin{abstract}
Ayşegül Nergis
School of Languages, Istanbul University, Turkey

Abstract. This study aimed to explore perceptions about two vocabulary instruction programs as reported from a cohort of 37 English for academic purposes (EAP) students enrolled in an academic speaking course in an English medium (EMI) university. While one group received concordance-based instruction of formulaic expressions (FE) for 10 hours, one group received a similar instruction of single academic vocabulary (AV). Participants were interviewed after pedagogical intervention was finalized. Semistructured interviews with each participant were audio-recorded and later transcribed verbatim for qualitative thematic analysis. Findings showed that both groups perceived vocabulary intervention they received to be useful for their academic needs and for enhancing their awareness about contextual use of academic vocabulary and formulaic expressions. As a third theme, the FE group emphasized the contribution of learning FE to their confident performance in $L 2$ whereas the $A V$ group differently reported that they enjoyed systematicity of $A V$ instruction. Pedagogical implications of findings were discussed.
\end{abstract}

Key words: perceptions, EAP, English-medium instruction, vocabulary instruction, concordance-based instruction

\section{LEARNERS' PERCEPTIONS IN EAP AND EMI}

Vocabulary is widely accepted as an important component of EAP (Coxhead \& Boutorwick, 2018; Durrant, 2014, 2016; Evans \& Green, 2007; Gardner \& Davies, 2014; Malmström, Pecorari, \& Shaw, 2018; Uchihara \& Harada, 2018) and many studies discussed that acquisition of vocabulary contributes to different modalities of linguistic performance, such as writing (Cai, 2016) and speaking (McGuire and Larson-Hall , 2017; Nergis, 2018), as well as creating wordlists for EAP/ESP (Gardner and Davies, 2014;

Received December 03, 2020/Accepted December 15, 2020

Corresponding author: Ayşegül Nergis

Istanbul University, School of Languages, Kirazlı Mescit sk 31, Fatih, Istanbul, Turkey

Phone: +90212440 0000 • E-mail: aysegulnergis@gmail.com

ㄷ 2020 by University of Niš, Serbia | Creative Commons License: CC BY-NC-ND 
Nekrasova-Beker, Becker \& Sharpe, 2019; Pojanapunya, 2019). Recent research has also examined learners' and practitioners' perceptions in EAP and EMI contexts around the world (Coxhead, Dang, \& Mukai, 2017; Uchihara and Harada, 2018) due to rapid expansion of EMI universities and academic programs (Al-Mubireek, 2020; Li and Ruan, 2015; Le, Kettle, and Pillay, 2020; Liu, Chang, Yang, and Sun, 2011; Musdariah, Basri, and Rahman, 2020) and the role of vocabulary knowledge in EAP programs (Afsar and Movassagh, 2016; Pazoki and Alemi, 2019; Uchihara and Harada, 2018); however, academic learners' perceived needs about learning vocabulary are not vast.

Studies focusing on specific language skills have recently received some attention. In an extensive reading investigation, Ro (2016) found that extensive reading practices improved EAP learners' perceived vocabulary knowledge and reading rate. Phakiti and Li (2011) examined graduate students' perceived problems about academic reading and writing and found that some students had problems with integrating vocabulary into their writing and remembering the appropriate words for their assignments. In a recent study, Jou (2017) explored advanced EAP students' opinions about an academic writing textbook. Findings showed that some participants thought focused vocabulary given in the book were easy and they suggested presenting more difficult items in context, not as isolated items on a list. In a rather interesting study, Hammond (2018) devised a phrasebook and conducted an evaluation study. Participants were mostly satisfied with the project because it was easy to use and also helpful for their academic assignments because the target items were introduced according to their function (for example, defining a concept, introducing the focus). Coxhead et al. (2017) examined postgraduate students and lecturers' opinions about an EAP program in a university in New Zealand and found that they had difficulties in fluency, accents, rates of speech and cultural differences in speech. In a more recent study, Youn (2018) examined perceived needs of L2 pragmatics in an EAP program and showed that for all stakeholders, learning formulaic language was a major need for L2 communication.

Although there is substantial focus on perceptions about writing (Wette, 2018), reading (Ro, 2016) and testing (Gu and So, 2015; Huang, 2018) in EAP/ESP, studies looking into speaking are quite rare. Furthermore, studies looking into learners' perceptions about vocabulary intervention in EAP are also not in abundance. This study aims to address this gap.

\section{VOCABULARY INSTRUCTION IN EAP}

Recently, there has been a growing interest in research about vocabulary knowledge in EAP and EMI. Some of these studies looked into testing of vocabulary knowledge (Fitzpatrick and Clenton, 2017; Paribakht and Webb, 2016), the relationship between vocabulary knowledge and reading in EAP (Nergis, 2013) and academic writing (Cai, 2016; Coxhead, 2012; Malmström, Pecarori, and Gustafsson, 2016) and reported about concrete contributions of vocabulary instruction to L2 production. For example, Al Hassan and Wood (2015) found that instruction of lexical phrases improved academic writing. As reported by Cai (2016), graduate students in an EMI setting can acquire considerable gains in receptive knowledge of formulaic language in rewriting tasks with the help of instruction on genre knowledge and genre-specific formulaic expressions. Le-Thi, Rodgers and Pellicer-Sánchez (2017) conducted an instructional study with low proficiency learners in Vietnam. They compared the effects of teaching FE explicitly through concordances versus traditional course book instruction. They found that explicit teaching of FE enhanced 
learners' test knowledge of academic vocabulary. They suggested that language instructors should consider integrating explicit teaching of FE in context even with the support of textbooks containing meaning-focused vocabulary learning tasks and activities. These studies clearly show that vocabulary instruction can lead to better written production in L2.

In addition to writing, speaking in EAP has also been reported to be enhanced by vocabulary instruction. For example, Wood (2009) examined an ESL learner's fluency gains after a receiving 6 week focused instruction of FE. The Japanese learner listened to audio-recordings and studied transcripts of native speakers by paying focused attention on hesitation markers (such as pauses and repetitions) and FE in speech. Then she completed dicto-gloss and jigsaw activities involving the target $\mathrm{FE}$ and also practiced their use in speaking activities that moved from controlled (for e.g. 4/3/2 procedure) and less controlled tasks (such as free talk). The result of the study was an increase in fluency measures and complex use of FE in speech, indicating that positive changes in speech (in terms of speed and proper use of complex structures) might be a result of learning the real-life use of FE and practicing them explicitly and repetitively.

Studies with larger groups and more advanced level of proficiency attempted to test effects of learning of FE in instructional settings with learners with different L1 background. For example, Boers, Eyckmans, Kappel, Stengers and Demecheleer (2006) investigated the effect of noticing method of FE learning on L2 learners' ability to build a repertoire of FE. During 22 hours of instruction, the experimental group completed activities involving noticing of useful language (FE) and the comparison group studied single words. At the end of the course, the experimental group who acquired a large amount of FE came across as more proficient speakers according to judges. However, findings of this study were not confirmed with a cohort of learners of Spanish (Stengers, Boers, Housen, and Eyckmans, 2010) which indicates, according to Boers and Lindstromberg (2012), that paying attention to a given word once or twice may not be enough to store it in memory in the long term.

Possible benefits of vocabulary instruction in EAP through corpus data and concordances have been discussed in literature for a long time now. It is widely discussed that using corpus data in classrooms (which is also called Data Driven Learning by Johns, 1991) can develop metacognitive skills as well as linguistic awareness, lead to learner autonomy (Boulton, 2009) and are usually found to be effective and perceived well by learners. For example, in a recent study, Bridle (2019) found that graduate Chinese learners had positive opinions about corpus-based instruction; however some participants stated that it was also a non-practical way of learning because it took a lot of time and effort. Similarly, in a 2014 study, Geluso and Yamaguchi found that corpus-based instruction was perceived to be useful especially for speaking by Japanese university students. In a qualitative study conducted in an EMI setting in Turkey, Ang (2006) found that university students in an EAP program had positive attitudes towards concordance as a useful tool because they enhance learner awareness about formulaic language use in assigned articles and increase motivation to become autonomous learners.

It is clear from this summary that EAP learners support the idea of learning academic vocabulary (Afsar and Movassagh, 2016; Pazoki and Alemi, 2019; Youn, 2018), specifically by way of using concordances or contextual cues (Bridle, 2019). However, it is still unclear how they perceive concordance-based vocabulary instruction in relation to their academic study skills and speaking in L2. The current study will address this problem by way of examining learners' point of view of two different vocabulary interventions in an EAP program in an EMI setting. 


\section{THE STUDY}

As a part of a larger study, the current qualitative investigation aimed to explore L2 learners' perceptions about two academic vocabulary interventions. In accordance with this aim, the following research question as formulated:

What are the participating EAP students' perceptions about concordance-based learning of academic vocabulary and formulaic expressions?

In order to address this research question, two groups of EAP learners were assigned either into academic vocabulary intervention (AV) group or academic formulas (FE) intervention group. After receiving concordance-based instruction for 5 consecutive weeks, participants were interviewed about their opinions on the intervention they received. Thematic data analysis was used to elicit recurring patterns in data (Braun and Clarke, 2006).

\section{PARTICIPANTS AND THE CONTEXT OF THE STUDY}

Participants were 37 EAP learners enrolled in an academic speaking course in an English medium-instruction university in Istanbul, Turkey. The age range was between 18 and 22, with a group mean of 19,67. 21 participants were male and 16 were female. All participating students were found to be successful according to a standardized language test (equivalent of TOEFL IBT 80) and registered into a freshmen EAP course with a special focus on academic speaking. The course was designed around the content of global problems and aimed to equip students with skills and knowledge that could help them do academic presentations and discussions in EMI. In the beginning of the semester, both groups were informed that they would take part in a research study and participation was on voluntary basis. Participants signed a standard informed consent form prepared by the university council.

\section{INTERVENTION}

Two groups of EAP learners received vocabulary intervention as part of their regular syllabus for five weeks. While one group $(n=19)$ received focused instruction of single academic $(A V)$ words, another group $(n=18)$ received focused instruction of formulaic expressions (FE). Intervention started at the third week of the semester; therefore, participants were familiar with the course requirements and communicative EAP tasks.

Lesson plans for each group was very similar, only the target items learned and practiced were different. The regular syllabus was a content-based EAP syllabus with a special focus on academic communication skills. The content of the course was focused on world problems and solutions; tasks involved EAP tasks designed for advanced learners of academic English such as research, discussion and presentation tasks and involved collaboration in small groups or pairs. Each lesson followed a presentation-practice-production cycle and visual materials and concordances were presented on a slide via a projector.

Lessons typically started with a 5-minute warm-up session that involved examination of and discussions about a global problem. In this part, the instructor used pictures and videos to activate background knowledge and encourage active participation. After the warm-up session was finalized, participants were given a handout that included the target items (formulaic expressions for the FE group and single academic vocabulary for the AV group), concordances that assisted them about their use and a worksheet that tested 
participants' learning of the target items at the end of each session. Concordances and endof-the-session worksheets used in the handouts were elicited from Michigan Corpus of Academic Spoken English (MICASE) website and adapted for classroom use by deleting repetitions and pause markers such erm and uhh so that students would not feel encouraged to use them in their speech. The rationale for using the concordances from spoken academic corpus was to show participants how each item was used in real-life academic spoken discourse and therefore, make learning of these items more meaningful for them.

In order to present the target items, the instructor projected a slide containing concordances on a white screen. Participants were instructed to examine each concordance and read them aloud. Then, they talked about their use in real-life academic contexts in pairs or small groups. At the practice stage, participants completed communicative tasks such as individual, pair and group discussions, pair and group research activities and short oral reports. Task requirements were projected on a slide on the white screen; participants also used the handouts that included the target items and concordances. They were instructed to use 3 to 5 target items in each task given. While participants were engaged in tasks, the instructor monitored their use of items, sometimes encouraging individual students to refer to the list of target items they were given more often. This part of the session usually took around 20-30 minutes. In the remaining minutes (production stage), participants were involved in less controlled tasks such as pair presentations and oral reports and were verbally instructed to use 3 to 5 target items in their speech. At this stage, participants were more familiar with the target items and were able to use them more easily and freely in their oral production. Each class hour was 45 minutes and students met their instructor for 3 hours a week. The first two hours of class time was allocated for the intervention. In the third hour, students prepared their term projects.

The handout also contained a worksheet that tested participants' learning of the target items at the end of each session. 7 to 11 items were learned and practiced in each session and during the intervention, the AV group learned and practiced a total of 82 items and the FE group learned 80 formulaic expressions. The list of target items was prepared by scanning popular academic speaking course books (formulaic expressions) and classroom texts (academic vocabulary) and triangulated by checking their frequency in two spoken academic corpora, MICASE and British Academic Spoken English (BASE) for FE and in Academic Wordlist (Coxhead, 2000) for AV. And finally, expert opinion was taken from experienced EAP instructors to determine whether these items were worth teaching in the current EAP context (as suggested by Ellis, Simpson-Vlach and Maynard, 2008, vocabulary used in the intervention was triangulated with frequency based information and instructor insight). Target FE taught were also presented according to their functions (for example, for function of sequencing ideas, FE list included items like 'last but not least, I want to focus on, this brings us to, for starters') and the list of AV (for each week) from the weekly assigned readings and videos. The instructor was a $\mathrm{PhD}$ candidate in English Language Teaching and received training on how to carry the intervention. Two pilot studies were also conducted with the same instructor and strict lesson plans were followed.

\section{DATA COLLECTION AND ANALYSIS}

This study was designed to explore two groups of freshmen EAP students' perceptions about vocabulary instruction they received over 5 weeks. A qualitative research design was adopted and data was collected through semi-structured interviews. After vocabulary intervention was finalized, participants were interviewed by the researcher about their 
impressions of the instruction they received. Interviews were conducted in the participants' first language (Turkish). Interviews were audio-recorded in a silent room with participants' consent and later transcribed verbatim. The participants responded to the Turkish translations of the following question set:

Participants were first asked to briefly describe a typical class. The purpose for asking this question was to stimulate retrospective thinking about the intervention they received. Then they were asked to elaborate on what they generally thought about the instruction (i.e. what they found prominent, easy or challenging, beneficial, useful or uninteresting). After that, they were invited to elaborate on their impressions on the vocabulary instruction they received (in terms of benefits and/or challenges) and explain whether (and if so, why and how) they were planning to use the target items they learned and practiced.

Participation in the study was on voluntary basis; a total of 37 participants were interviewed, with each session lasting around 3 minutes. A total of 109 minutes of speech was recorded. The recordings were transcribed and coded systematically in order to elicit the most frequently occurring themes. Before analyzing the main body of data, intercoder reliability was calculated. According to Denzin and Lilcoln (2000), it is imperative to ensure the credibility of open coding procedure by including an external rater. Therefore, one external coder participated in open data coding procedure. The external coder was familiar with qualitative coding procedures and was a PhD candidate in ELT at the time of data analysis. She coded $25 \%$ of the data. The codes found by the volunteer coder were compared against the researcher's codes. Intercoder reliability coefficient was found to be $k=0.87$. Disagreements over the codes in the sample were solved through discussion and the researcher coded the entire data later on to detect reoccurring themes in the interview data. The themes were also confirmed by the external coder and another researcher with a $\mathrm{PhD}$ in ELT.

\section{FINDINGS}

A total of 137 codes were detected in the interviews with the formulaic expressions group participants $(n=18)$, whereas 61 codes were detected in the academic vocabulary group interviews $(n=19)$. Table 1 below summarizes the number of themes that emerged from the interviews.

Table 1 Themes and Categories According to Groups

\begin{tabular}{lll}
\hline Themes & $\mathrm{f}$ & $\%$ \\
\hline Formulaic Expressions Group $(n=18)$ & & \\
Academic usefulness & 65 & 48 \\
Awareness about contextual use & 39 & 28 \\
Confidence & 33 & 24 \\
Academic Vocabulary Group $(n=19)$ & & \\
Academic usefulness & 25 & 40 \\
Awareness about contextual use & 26 & 42 \\
Systematicity & 10 & 17 \\
\hline
\end{tabular}

As can be seen, similar patterns emerged from the interviews with two groups of students. Both groups elaborated that focused instruction of vocabulary were useful in their academic studies and concordances enabled them to realize how target vocabulary are used 
in academic context. The main difference is observed in the last theme. While the formulaic expressions group cited the importance of confidence they gained by the explicit instruction of FE, the academic vocabulary group focused their opinions on systematicity of the instruction they received.

\subsection{Common Themes in Both Intervention Groups}

\subsubsection{Theme 1: Academic Usefulness}

Participants' responses displayed a clustering around the central theme of Academic Usefulness for both groups. This theme included the most comprehensive category of codes for both groups. As for the formulaic expressions group, the most significant categories under this theme were perceived effectiveness (of concordance-based vocabulary instruction) for the participants' EAP/ESP needs, its meaningfulness and functionality, lasting effect and its positive effect on the perceived quality of speech.

As described in the Methodology, the present study was an instructional study that integrated two different types of vocabulary intervention into the regular EAP program. EAP programs aim to cater for EAP and ESP needs of students and this result indicates that the FE instruction catered for their needs and more. Participant 10 in the FE group stated:

I keep the notes of this course. I used them in the HR course last week. I had a presentation and used them there. I think my professor was also pleased.

The participant further stated that such structures should be taught in their other classes because they need them in all of their EMI courses. Four of the 18 participants in the FE group stated the same idea, emphasizing their need to learn more FE for their use in other classes. By referring to the use of concordances coming from spoken academic corpora, participant 7 explained:

In department classes, we are required to do a lot of presentations, but we do not know so many chunks. We hear them often, but we do not use them. It (the instruction of FE) gave me the idea to use them after seeing examples from other classes.

The AV group participants shared similar ideas about learning academic vocabulary in concordances and its contribution to their EAP/ESP needs. Six participants specifically emphasized that they started using the target items in their EMI classes.

The next cluster of ideas that emerged under this theme is related to how learning vocabulary was perceived to be meaningful and easy thanks to using concordances. Some participants in the FE group stated that their professors and teachers usually gave them papers and articles to read, but they did not include any FE and their teachers did not focus on teaching such meaningful and functional parts of speech. Participant 11 stated that he found the instruction meaningful because FE are a part of natural speech and they are almost always neglected by other teachers.

Eight participants in the FE group stated that seeing the FE in concordances helped them to realize how they are used in real life. According to them, use of concordances and practicing FE in communicative activities was a meaningful method and helped them to remember FE easily while they were speaking. Similar ideas were verbalized by the AV group participants as well. Participant 2 remarked that he

Liked the way I saw each of them in sentences, in spoken sentences (concordances)... Sometimes I remember those sentences while using those words.

Perceived quality of speech was another category that emerged from the interview data. Some participants stated that the use of FE in their speech increased the content 
quality of their speech. They mostly referred to the amount of words they used in their speech; for example, participant 12 stated that FE

Helped them to speak more and have more content in their speech.

Participant 6 emphasized the role of FE use in decreasing the planning effort in speech and said that

Chunks are useful. They serve me well while I am speaking. I am speaking effortlessly, rather than just trying to speak. I can say longer sentences and the content is good. I think my other teachers will also realize that.

Similarly, participant 8 explained that learning FE will help their future studies in many ways:

I needed this type of encouragement (to use FE) in an English class because the classes are going to get more difficult in years to come and the content of the classes and course requirements will get more difficult. By using FE, one can speak more and do even more difficult presentations.

The AV group participants also emphasized this point. For example, Participant 15 commented that he trusted in his speaking abilities more now because he learned a lot of new vocabulary and was planning to add more by practicing them in the same way he learned the target AV. He elaborated that he was

Aware that I need to learn a lot of vocabulary to speak better (in English). If we learn more vocabulary in this way, by practicing and repeating them often, we can remember them when we speak.

Lasting effect was the last cluster of responses that emerged around the theme of academic usefulness. Some participants in the FE group were more interested in learning and using FE more because they can be stored in mind for a longer period and they are not so easy to forget in contrast to single words. Moreover, three participants stated that forgetting the FE they learned would be very difficult because they learned them in context, emphasizing that they learned them by heart because they learned how each of them were used in real-life.

The same idea was emphasized more by the AV group participants. Nine participants cited the long term effect of instruction. Of all the responses by the two groups of participants, only one participant expressed that he was concerned about remembering all those words in the beginning of the instruction. However, he was later convinced that that was not required at all. In a similar vein, 13 participants in the AV group stated positive effects of AV instruction on their ability to remember the target items.

\subsubsection{Theme 2: Awareness About Contextual Use}

The second theme centered on Awareness about Concordances for both groups. The majority of participants in both groups stated that before the current vocabulary intervention, they were not aware of the possible uses of concordances in EAP classes. For many participants, Learning the Contextual Use of FE and AV was very important, because they were not fully aware of the contexts they were used in. In the FE group, Participant 1 responded to the interview questions by asking

Why should we not learn them as they are used in real life? Now that we saw that they are used like this in real life, why don't we learn all chunks like this?

Ten participants appreciated learning about the real life use of FE and emphasized that concordance helped them to realize the real function of the new FE they come across in their studies and overall language learning experiences. Along the same line, 12 participants in 
the AV group expressed positive comments on this idea. Participant 15 specifically stated that learning the functions of words in real communication was very useful and he felt like discovering the (English) language.

Variability was another category that emerged from the responses of the FE group participants. However, this idea was not significantly underlined in the AV group interviews. Some participants stated that they benefited from the concordances because they realized that FE, even if they seemed conventional, actually had variability: they had different forms than participants had realized and they were used in different ways than they had thought. 6 students stated that they perceived concordances as a new way of learning, which is linked to the next category.

The last category was the Use of Search Engines as a tool of learning chunks. Closely linked to the two categories cited above, the use of search engines was a popular strategy among the participants in both groups inspired by the vocabulary intervention they received. Some participants stated highly positive opinions about concordance and stated that concordance was very similar to one of the strategies they used very often in their studies and overall language learning experiences. Participant 4 (FE) explained:

Search engines provide similar services. When I learn a new word or structure, I search it online to see how it is used in real life.

\subsection{Different Themes in $\mathrm{AV}$ and $\mathrm{FE}$ Groups}

\subsubsection{Theme 3 (for only the FE Group): Self-confidence}

Self-confidence was the last theme that the responses of the FE group clustered around. The categories that emerged under this theme were increase in motivation to speak and maturity of speech. This theme is not found in the academic vocabulary group interviews. The FE students generally were satisfied with the vocabulary instruction because learning FE encouraged them to be more confident while speaking and helped them deal with lack of confidence. Participant 9 explained how learning FE helped her to overcome her shyness as follows:

I was able to think more on the content of what I would say next because chunks helped me.

Participant 2, on the other hand, did not have the same problem, but she stated that learning FE has helped her to produce longer utterances. Similarly, Participant 1 remarked that students "can speak faster by using FE" because they feel "free", while another student (Participant 14) said he was "more motivated to speak in this class compared to other English classes thanks to raised awareness that "native speakers use chunks often" and he was able to see that he could use them as well. Participant 16 said that she was more confident now because she could see that she could speak almost as fast as a native speaker. Some students also added that they were happy they could speak more and faster in English.

Another category that emerged under this theme was Maturity of speech, referring to the increase in perceived proficiency as defined by the students. 6 students in the FE group stated that FE made their speech more "mature". Participant 3 explained what she meant by maturity was being able to deal with speed and content quality of speech at the same time. Participant 11 explained what he means by maturity of speech by saying that his speech quality was balanced. By these comments, it is clear that FE instruction helped students to have a more balanced view of speed of speech and content quality of speaking tasks. 


\subsubsection{Theme 3 (for only the AV Group): Systematicity of Instruction}

Systematicity was the last theme that the responses of the AV group clustered around. This theme is not found in the FE group interviews. Participants in the AV group were specifically satisfied with the vocabulary instruction they received because they perceived that systematic learning of vocabulary through concordances and practicing their use in communicative activities was natural. Participants who agreed on this idea generally stated that $\mathrm{AV}$ instruction increased the fun in vocabulary learning and probably increased their motivation. They also expressed that this systematic learning of academic vocabulary was a quality learning experience. For example, Participant 14 noted that

I usually hate studying vocabulary. I don't like dictionaries. I don't find them natural. But this was very natural. Overall, when I look at everything (at once), I had everything under my hand. Very useful, I think. It was so functional.

Participant 8 in the AV group emphasized that he appreciated the systematic learning of vocabulary because vocabulary learning, according to him, is difficult, but "this instruction was really fun" for him and was a high quality learning experience. Ten participants stated positive opinions on the systematicity of the instruction.

\section{DISCUSSION AND IMPLICATIONS}

The current investigation was designed to explore learners' perceptions about instruction of academic vocabulary and fixed expressions in an EAP program. Major findings of this study are congruent with previous studies. For example, Ang (2006) found that freshmen students in an EAP setting perceived the use of concordances as a useful tool to enhance their awareness about formulaic language use in research articles. In fact, three major themes that emerged from qualitative analysis were very similar to this study: increased motivation, language awareness and learner autonomy. Recent research has also found similar themes in participants' perception about use of contextual cues in vocabulary learning (Hammond, 2018; Jou, 2017). The literature also supports that concordance is frequently used to help L2 vocabulary learning in EAP and is also perceived well by academic learners with different L1 and varied levels of proficiency (Bridle, 2019; Gels and Yamaguchi, 2014). Therefore, materials developers could consider integrating contextualized vocabulary exercises into course materials for their positive effect on perceived learning outcomes (Stengers \& Boers, 2015).

Participants' responses in both the FE and the AV group indicated that they were happy about learning vocabulary in a functional and meaningful way; however, they were assigned into one of these groups so they did not receive intervention involving both AV and FE. Indeed, Afsar and Movassagh (2016) found that academic learners wish to be taught both AV and FE in EAP; therefore, it can be suggested that EAP materials include both types of vocabulary to satisfy the learning needs of EAP learners. However, studying with long lists of vocabulary is sometimes perceived as a difficult job according to previous research. For example, Hammond (2018) found that this idea was not received well by EAP learners. As also suggested by Simpson (2004), participants in her study required the target items to be grouped and presented according to their function. This was implemented in the intervention in this study and was found conducive to a stronger learning in the long-term by the participating EAP students as well.

In this study, the focused vocabulary instruction that requires repetitive use of the target vocabulary in communicative tasks was generally found to be a useful learning method by 
EAP students in both groups. Indeed, previous research (Jones and Haywood, 2004; McGuire and Larson-Hall, 2017) provided concrete evidence in support of this method in relation to academic speaking skills as opposed to instructional methods involving implicit learning activities (for example, Boers et al., 2006; Stengers et al., 2010). Findings of this study also confirmed this from the perspective of learners. Participants stated that they benefited from the explicit instruction because it helped them understand the contextual use and variability of FE and AV and also retrieve the target words with ease in the long run. They also stated that the instruction changed their attitudes towards learning new vocabulary and helped them build a better repertoire which enhanced their retrieval of words in EMI assignments as well. This might indicate that explicit instruction of vocabulary in EAP is a rewarding experience for advanced learners because examining AV and FE and their relationship with the context in real life makes more sense to them.

Kormos and Prefontaine (2017) discussed that there is need for more research to examine L2 learners' perceptions about speaking tasks used in foreign language classrooms and found that perceived task difficulty is linked to vocabulary requirements of the given spoken task. With a group of Iranian learners, Pazoki and Alemi (2019) also found that academic learners' motivation to learn vocabulary is majorly driven by their academic needs. In line with the same idea, findings of the current investigation showed that participants were clearly aware of their EAP/ESP needs and attempted to please their professors' perceived expectations in the current EMI setting with the new vocabulary they acquired. This study also revealed that in both groups, learners had positive attitudes towards concordance-based vocabulary learning in that it develops them as autonomous learners in EMI. Indeed, concordance-based learning is widely perceived to enhance metacognitive awareness and learner autonomy (Boulton, 2009). Previous research has consistently confirmed this finding (Bridle, 2019; Geluso and Yamaguchi, 2014; Hammond, 2018).

Moreover, differently from the AV group, the FE group expressed that the FE instruction helped them to speak more confidently in L2. This is frequently discussed in previous research (Kormos, 2006; Segalowitz, 2010; Wood, 2012). Due to a larger storage of FE repertoire, participants felt that they could produce longer runs and could plan their speech ahead. This is also congruent with previous research which found that use of FE results in longer runs in L2 speech (Towell, Hawkins, and Bazergui, 1996). The participants also stated that FE instruction increased their motivation to speak in L2. According to Segalowitz (2010), fluency acquisition is affected by "various socially grounded factors" (p. 120). Motivation and self-confidence are among these factors. Also, some participants in the formulaic expressions group stated that learning FE made them feel they were speaking faster and in a more "mature" way that allowed them to keep the balance between matching up the speed of their speech with an effort to deliver content in an appropriate manner. In a recent study, Wood (2016) found that L2 speakers might present fluctuating levels of motivation while speaking in L2. A focused-FE instruction could help L2 speakers to catch up with demanding motivational requirements of L2 oral tasks to a great extent, as can be observed in the participants' justifications in this study. In the AV group, participants specifically perceived concordance-based instruction as a quality learning experience because it was systematic. Students expressed that advanced academic vocabulary can still be fun to learn and practice for them. This finding was also confirmed previous studies (Geluso and Yamaguchi, 2014; Hammond, 2018; Jou, 2017) which found that learning long lists of academic vocabulary can be made fun and easy for learners if target items are presented and practiced in a systematic way. 
To summarize the pedagogical implications, EAP instructors could provide their students with opportunities to learn new vocabulary in context through concordances for its positive effects on learners' perceptions about building a good repertoire of productive vocabulary, ensuring quality of oral production and gaining confidence. However, in line with previous research, it is suggested that this goal can be achieved only through repetitive practice in meaningful and communicative tasks. Moreover, in this study, EAP learners were highly aware of their academic needs and were eager to test the effects of their learning in EMI settings by way of getting confirmation from their professors about their performances (specifically observed in Academic Usefulness theme), emphasizing the importance of building sound relations between EMI and EAP programs. Although the participants were mostly satisfied with the vocabulary intervention, some participants stated that they found the program a bit loaded at first. Examining every new word or FE in context seemed difficult or time consuming. However, as the time progressed they believed more in benefits of learning vocabulary in context and even started to apply this as a strategy to learn new vocabulary on search engines. Therefore, it can be discussed that it takes time for some students to adapt into concordance-based vocabulary instruction, but overall, they perceive it as a rewarding experience for their academic studies.

\section{REFERENCES}

Afsar, H. S., \& Movassagh, H. (2016). EAP education in Iran: Where does the problem lie? Where are we heading? Journal of English for Academic Purposes, 22, 132-151.https://doi.org/10.1016/j.jeap.2016.04.002

AlHassan, L., \& Wood, D. (2015). The effectiveness of focused instruction of formulaic sequences in augmenting L2 learners' academic writing skills: A quantitative research study. Journal of English for Academic Purposes, 17, 51-62. https://doi.org/10.1016/j.jeap.2015.02.001

Al-Mubireek, S. (2020). An attitude/motivation test battery (AMTB) of English language learning among students across genders, tracks and proficiency levels at a leading Saudi university. Asian EFL Journal 24(4), 26-50.

Ang, F. (2006). Effectiveness of Corpus Consultation through Concordancing on the Formulaic Academic Language Use of Freshman ELT Students. (Unpublished master's thesis). Bogazici University, Istanbul, Turkey.

Boers, F., Eyckmans, J., Kappel, J., Stengers, H., \& Demecheleer, H. (2006). Formulaic sequences and perceived oral proficiency: Putting a lexical approach to the test. Language Teaching Research 10, $245-261$. https://doi.org/10.1191/13621688061r195oa

Boers, F., \& Lindstromberg, S. (2012). Experimental and intervention studies on formulaic sequences in a second language. Annual Review of Applied Linguistics 32, 83-110. https://doi.org/10.1017/S0267190512000050

Boulton, A. (2009). Testing the limits of data driven learning: Language proficiency and training. ReCALL, 17 (1), 47-64.

Braun, V., \& Clarke, V. (2006). Using thematic analysis in psychology. Qualitative Research in Psychology, 3 (2), 77-101. https://doi.org/10.1191/1478088706qp063oa

Bridle, M. (2019). Learner use of a corpus as a reference tool in error correction: Factors influencing consultation and success. Journal of English for Academic Purposes 37, 52-69. https://doi.org/10.1016/j.jeap.2018.11.003

Cai, L. J. (2016). An exploratory study on an integrated genre-based approach for the instruction of academic lexical phrases. Journal of English for Academic Purposes, 24, 58-74. http://dx.doi.org/10.1016/j.jeap.2016.09.002

Coxhead, A. (2000). A new academic word list. TESOL Quarterly, 34, 213-238. https://doi.org/10.2307/3587951

Coxhead, A. (2012). Academic vocabulary, writing and English for academic purposes: Perspectives from second language learners. RELC Journal, 43(1), 137-145. https://doi.org/10.1177/0033688212439323

Coxhead, A., \& Boutorwick, T. J. (2018). Longitudinal vocabulary development in an EMI international school context: Learners and texts in EAL, Maths and Science. TESOL Quarterly, 52(3), 588-610. https://doi.org/10.1002/tesq.450

Coxhead, A., Dang, T.N.Y., \& Mukai, S. (2017). Single and multi-word unit vocabulary in university tutorials and laboratories: Evidence from corpora and textbooks. Journal of English for Academic Purposes, 30, 6678. https://doi.org/10.1016/j.jeap.2017.11.001

Denzin, N. K., \& Lincoln, Y. S. (2000). Handbook of qualitative research. Thousand Oaks, Calif: Sage Publications.

Durrant, P. (2014). Discipline and level specificity in university students' written vocabulary. Applied Linguistics, 35, 328-356. https://doi.org/10.1093/applin/amt016 
Durrant, P. (2016). To what extent is the Academic Vocabulary List relevant to university student writing? English for Specific Purposes, 43, 49-61.

Ellis, N. C., Simpson-Vlach, R., \& Maynard, C. (2008). Formulaic language in native and second language speakers: Psycholinguistics, corpus linguistics, and TESOL. TESOL Quarterly, 42(3), 375-396. https://doi.org/10.1002/j.1545-7249.2008.tb00137.x

Evans, S., \& Green, C. (2007). Why EAP is necessary: A survey of Hong Kong tertiary students. Journal of English for Academic Purposes, 6, 3-17. https://doi.org/10.1016/j.jeap.2006.11.005

Fitzpatrick, T., \& Clenton, J. (2017). Making sense of learner performance on tests of productive vocabulary knowledge. TESOL Quarterly, 51, 844-867. https://doi.org/10.1002/tesq.356

Gardner, D., \& Davies, M. (2014). A new academic vocabulary list. Applied Linguistics, 35(3), 305-327. https://doi.org/10.1093/applin/amt015

Geluso, J., \& Yamaguchi, A. (2014). Discovering formulaic language through data-driven learning: Student attitudes and efficacy. ReCALL 26(2), 225-242. https://doi.org/10.1017/S0958344014000044

Gu, L., \& So, Y. (2015). Voices from stakeholders: What makes an academic English test 'international'? Journal of English for Academic Purposes, 18, 9-24. https://doi.org/10.1016/j.jeap.2014.10.002

Hammond, K. (2018). "I need it now!" Developing a formulaic frame phrasebank for a specific writing assessment: Student perceptions and recommendations. Journal of English for Academic Purposes 31, 98- 105.

Huang, L. (2018). A call for critical dialogue: EAP assessment from the practitioner's perspective in Canada. Journal of English for Academic Purposes, 35, 70-84. https://doi.org/10.1016/J.JEAP.2018.07.005

Johns, T. (1991). Should you be persuaded: Two samples of data-driven learning materials. ELR Journal, 4, 1-16.

Jones, M., \& Haywood, S. (2004). Facilitating the acquisition of formulaic sequences: An exploratory study. In N. Schmitt (Ed.), Formulaic sequences (pp. 269-300). Amsterdam, the Netherlands: John Benjamins.

Jou, Y. (2017). Hidden challenges of tasks in an EAP writing textbook: EAL graduate students' perceptions and textbook authors' responses. Journal of English for Academic Purposes, 30, 13-25. https://doi.org/10.1016/j.jeap.2017.10.001

Kormos, J. (2006). Speech Production and Second Language Acquisition. New Jersey: Lawrence Erlbaum Associates.

Kormos, J., \& Prefontaine, Y. (2017). Affective factors influencing fluent performance: French learners' appraisals of second language speech tasks. Language Teaching Research, 21(6), 699-716. https://doi.org/ $10.1177 / 1362168816683562$

Le, L. P., Kettle, M., \& Pillay, H. (2020). Using corpus analysis in a needs analysis of key English vocabulary for petroleum engineers in Vietnam. Asian EFL Journal, 24(1), 45-68.

Le-Thi, D., Rodgers, M. P. H., \& Pellicer- Sánchez, A. (2017). Teaching formulaic sequences in an Englishlanguage class: The effects of explicit instruction versus coursebook instruction. TESL Canada, 34(3), 111139. https://doi.org/10.18806/tesl.v34i3.1276

Li, C., \& Ruan, Z. (2015). Changes in beliefs about language learning among Chinese EAP learners in an EMI context in Mainland China: A socio-cultural perspective. System, 55, 43-52. https://doi.org/10.1016/ j.system.2015.08.010

Liu, J., Chang, Y., Yang, F., \& Sun, Y. (2011). Is what I need what I want? Reconceptualising college students' needs in English courses for general and specific/academic purposes. Journal of English Academic Purposes, 10, 271-280. https://doi.org/10.1016/j.jeap.2011.09.002

Malmström, H., Pecorari, D., \& Gustafsson, M. (2016). Coverage and development of academic vocabulary in assessment texts in English medium instruction. In S. Göpferich \& I. Neumann (Eds.), Developing and assessing academic and professional writing skills (pp. 45-69). Frankfurt: Peter Lang Publishing Group.

Malmström, H., Pecorari, D., \& Shaw, P. (2018). Words for what? Contrasting university students' receptive and productive academic vocabulary needs. English for Specific Purposes, 50, 28-39. https://doi.org/10.1016/j.esp. 2017.11.002

McGuire, M., \& Larson-Hall, J. (2017).Teaching formulaic sequences in the classroom: Effects on spoken fluency. TESL Canada Journal, 34(3), 1-25. https://doi.org/10.18806/tesl.v34i3.1271

Musdariah, A., Basri, M., \& Rahman, Q. (2020). Lecturers' Attitude on Blended Learning-Based Instruction in Teaching English for Business in Indonesian Vocational Higher Education. The Asian ESP Journal 16(4), 290-302.

Nekrasova-Beker, T., Becker, A., \& Sharpe, A. (2019). Identifying and teaching target vocabulary in an ESP course. TESOL Journal, 10(e00365), 1-27. https://doi.org/10.1002/tesj.365

Nergis, A. (2013). Exploring the factors that affect reading comprehension of EAP learners. Journal of English for Academic Purposes, 12(1), 1-9. https://doi.org/10.1016/j.jeap.2012.09.001

Nergis, A. (2018). The effect of explicit instruction of formulaic sequences on L2 oral fluency (Unpublished doctoral dissertation). Yeditepe University, Istanbul, Turkey.

Pazoki, S. J., \& Alemi, M. (2019). Engineering students' motivation to learn technical English in ESP courses: Investigating Iranian teachers' and students' perceptions. RELC Journal, Online First, 1-15. https://doi.org/ $10.1177 / 0033688218811371$ 
Paribakht, T. S., \& Webb, S. (2016). The relationship between academic vocabulary coverage and scores on a standardized English proficiency test. Journal of English for Academic Purposes, 21, 121-132. https://doi.org/10.1016/j.jeap.2015.05.009

Phakiti, A., \& Li, L. (2011). General Academic Difficulties and Reading and Writing Difficulties among Asian ESL Postgraduate Students in TESOL at an Australian University. RELC Journal, 42(3), 227-264. https://doi.org/10.1177/0033688211421417

Pojanapunya, P. (2019). Tailoring academic words to multidisciplinary EAP classes. TESOL Journal, 10(e439), 1-16. https://doi.org/10.1002/tesj.439

Ro, E. (2016). Exploring teachers' practices and students' perceptions of the extensive reading approach in EAP reading classes. Journal of English for Academic Purposes, 22, 32-41. https://doi.org/10.1016/j.jeap.2016.01.006

Segalowitz, N. (2010). Cognitive Bases of Second Language Fluency. New York: Routledge.

Simpson, R. (2004). Stylistic features of academic speech: The role of formulaic expressions. In U. Connor \& T. A. Upton (Eds.), Discourse in the Professions: Perspectives from corpus linguistics (pp. 37-64). Amsterdam: John Benjamins.

Stengers, H., Boers, F., Housen, A., \& Eyckmans, J. (2010). Does "chunking" foster chunk-uptake? In S. De Knop, F. Boers, \& A. De Rycker (Eds.), Fostering language teaching efficiency through cognitive linguistics (pp. 99-117). Berlin, Germany: Mouton de Gruyter.

Stengers, H., \& Boers, F. (2015). Exercises on collocations: a comparison of trial-and-error and exemplar-guided procedures. Journal of Spanish Language Teaching, 2, 152-164. https://doi.org/10.1080/23247797.2015.1104030

Towell, R., Hawkins, R., \& Bazergui, N. (1996). The development of fluency in advanced learners of French. Applied Linguistics, 17, 84-119. https://doi.org/10.1093/applin/17.1.84

Uchihara, T., \& Harada, T. (2018). Roles of vocabulary knowledge for success in English-medium instruction: Self-perceptions and academic outcomes of Japanese undergraduates. TESOL Quarterly, 52(3), 564-587. https://doi.org/10.1002/tesq.453

Wette, R. (2018). Source-based writing in a health sciences essay: Year 1 students' perceptions, abilities and strategies. Journal of English for Academic Purposes, 36, 61-75. https://doi.org/10.1016/j.jeap.2018.09.006

Wood, D. (2009). Effects of focused instruction of formulaic sequences on fluent expression in second language narratives: A case study. Canadian Journal of Applied Linguistics, 12(1), 39-57.

Wood, D. (2012). Formulaic Language and Second Language Speech Fluency: Background, Evidence and Classroom Applications. London: Continuum International Publishing.

Wood, D. (2016). Willingness to communicate and second language speech fluency: An idiodynamic investigation. System, 60, 11-28. https://dx.doi.org/10.1016/j.system.2016.05.003

Youn, S. Y. (2018). Task-based needs analysis of L2 pragmatics in an EAP context. Journal of English for Academic Purposes 36, 86-98. https://doi.org/10.1016/j.jeap.2018.10.005

\section{PERCEPCIJE EAP STUDENATA O UČENJU ZASNOVANOM NA PODUDARNOSTI AKADEMSKOG REČNIKA I FORMULATIVNIH IZRAZA}

Ovo istraživanje je imalo za cilj da istraži percepcije za dva rečnička instrukciona programa kao što je saopšteno iz skupine od 37 studenata za Engleski jezik u akademske svrhe (EAP) koji su upisani na akademski govorni kurs na Engleskom univerzitetu (EMI). Jedna grupa je dobijala instrukcije zasnovane na podudarnosti formulativnih izraza 10 sati dok je druga dobijala slične instrukcije za jedan akademski rečnik. Učesnici su bili intervjuisani nakon što je pedagoško posredovanje završeno. Polustrukturirani intervjui za svakog učesnika su bili audio zapisani a kasnije doslovno prepisani radi kvalitetne tematske analize. Dobijeni rezultati pokazali su da obe grupe smatraju da su percepcije o vokabularu (rečniku) korisne za njihove akademske potrebe i za jačanje njihove svesti o kontekstualnoj upotrebi akademskog rečnika i formulativnih izraza. Takođe, grupa za formulativne izraze istakla je da učenje formulativnih izraza doprinosi sigurnijoj upotrebi jezika, dok je grupa za akademski rečnik - vokabular izvestila da su uživali u sistematičnosti instrukcija akademskog rečnika. Pedagoške implikacije ovog saznanja su diskutovane.

Ključne reči: percepcije, Engleski za akademske svrhe, Instrukcije za Engleski, rečničke instrukcije, instrukcije zasnovane na podudarnosti 